\title{
Gut commensal flora: tolerance and homeostasis
}

\author{
Maria Rescigno
}

Department of Experimental Oncology, European Institute of Oncology, Via Ripamonti 435, 20141 Milan, Italy

Email:maria.rescigno@ifom-ieo-campus.it

FI000 Biology Reports 2009, I:9 (doi: 10.34I0/BI-9)

The electronic version of this article is the complete one and can be found at: http://FI000.com/Reports/biology/content/I/9

\begin{abstract}
Commensal microorganisms are not ignored by the intestinal immune system. Recent evidence shows that commensals actively participate in maintaining intestinal immune homeostasis by interacting with intestinal epithelial cells and delivering tolerogenic signals that are transmitted to the underlying cells of the immune system.
\end{abstract}

\section{Introduction and context}

If we consider that our body is composed of ten times more microbial cells than mammalian cells, it becomes clear that microbes are required for the body to function properly [1]. Microbial genomes encode metabolic functions that humans have not fully evolved, including the ability to extract energy and nutrients from food. Microbes are also required for the correct development of the mucosal immune system. Germ-free rodents have smaller Peyer's patches (the organized lymphoid tissue of the intestine), negligible numbers of isolated lymphoid follicles and intraepithelial lymphocytes, and produce little secretory immunoglobulin A (sIgA) [2,3]. Furthermore, the induction and maintenance of oral tolerance (immunological tolerance of potential antigens that enter the body via the gastrointestinal tract) also requires microbial colonization of the gut early in life [2]. All this shows that the presence of microbes in the gut is not ignored; rather, 'sensing' of bacteria is important for the development and maintenance of intestinal immune homeostasis.

How bacteria interact with their host at mucosal surfaces is still an open question. The first cell types that encounter bacteria are probably the epithelial cells. It is not clear, however, whether this is a direct interaction, as epithelial cells are covered by a mucus layer that imposes a physical and electrically charged barrier to bacteria. Bacteria in the gut can also be bound by secretory IgA, which impedes their direct binding to epithelial cells.
Commensal microorganisms could also interact directly with immune-system cells, in particular with dendritic cells, which have been shown to cross the epithelial layer and interact directly with the contents of the gut lumen [4]. So we are left with several questions. What are the outcomes of bacteria-epithelium or bacteria-dendritic cell interactions? Do bacteria act directly on immune cells or indirectly via epithelial cells? How is immunological tolerance induced by commensals?

\section{Major recent advances}

It was initially believed that epithelial cells and commensals would not interact with each other because the commensals would not be able to access patternrecognition receptors (PRR) on the epithelial cells that recognize common microbial molecules. Indeed, PRRs (such as the Toll-like receptors (TLRs)) were thought to be expressed either intracellularly or exclusively on the basolateral membrane (that is, not exposed to the lumen) in epithelial cells - and would thus be inaccessible to non-invasive commensal bacteria. In the absence of this initial recognition, intestinal bacteria would simply be ignored by the mucosal immune system. Accumulating evidence is challenging this view, in part at least.

It has recently been found that TLRs are not restricted to the interior or the basolateral surface of epithelial cells. TLR-9 for instance, which is only expressed intracellularly in hematopoietic cells, is expressed on both apical and 
basolateral surfaces of epithelial cells [5]. And the outcome of its engagement on these two surfaces is different [6]. Engagement of TLR-9 on the apical surface leads to only partial activation of the transcription factor $\mathrm{NF}-\kappa \mathrm{B}$, a master regulator of inflammatory responses. In contrast, basolateral engagement of TLR-9 leads to nuclear translocation of NF- $\mathrm{BB}$ and activation of the signaling cascade that leads to the production of inflammatory cytokines. Interestingly, binding of apical TLR-9 inhibits the activation cascade induced by engagement of basolateral TLR-9. This indicates that as long as bacteria can bind to TLR-9 only from 'outside' of the body, the net response is inhibition of the inflammatory cascade. In agreement with this, engagement of TLRs in mice protects against experimental colitis [7-9] whereas mice lacking TLR-5 develop spontaneous colitis [10]. A final piece of evidence is that intestinal epithelial cells become tolerant to bacterial lipopolysaccharide (LPS) very early in an animal's life [11], indicating that bacteria-derived products are not ignored. Epigenetic mechanisms could be responsible for inducing and maintaining this tolerance by selectively inhibiting the expression of inflammatory genes and sparing those involved in the antimicrobial response [12]. Together, these findings indicate that epithelial cells do not ignore commensals, but rather that their 'sensing' of them actively protects against an inflammatory response.

What are the mechanisms underlying this protection? Incubation of human epithelial cells with non-invasive strains of Salmonella enteritidis leads to a reduction of NF- $\kappa \mathrm{B}$ activation and translocation to the nucleus $[13,14]$, and interaction with an abundant commensal bacterium, Bacteroides thetaiotaomicron, leads to premature egress of the RelA subunit of NF- $\mathrm{B}$ B from the nucleus [15]. Interestingly, inhibition of epithelial cell activation could also be indirect and depend on the concentrations of reactive oxygen species (ROS) induced by commensals [16]. ROS are responsible for inactivation of the catalytic cysteine residue of the protein $\mathrm{Ubc12}$, resulting in impaired ubiquitination of the NF- $\kappa B$ inhibitor I $\kappa B$ and thus in impaired NF- $\mathrm{B}$ activation [16]. Finally, it has been demonstrated that lipid A isolated from Gramnegative members of the phylum Bacteroidetes that abundantly populate the gut display either non-agonistic or antagonistic properties on TLR-4 [17].

A net result of epithelial cell-bacteria interaction is the inhibition of inflammatory signaling cascades via blockade of NF- $\kappa \mathrm{B}$ activation. However, to avoid inflammation, it is not sufficient just to inhibit epithelial cell activation. As mentioned above, dendritic cells can also interact with luminal bacteria. Dendritic cells express tight junction proteins and establish tight-junction-like structures with adjacent epithelial cells for direct bacterial uptake [4]. Dendritic cells could thus sense bacteria and be activated by commensals. Activated dendritic cells would then be able to get into draining lymph nodes, where they might activate T cells. Systemic immunity to commensal bacteria does not occur, however [18], which means that intraepithelial gut dendritic cells are somehow unable to initiate immunity. This is due to the specialized properties of resident gut dendritic cells, which differ from those of dendritic cells isolated from other lymphoid organs such as the spleen (reviewed in $[19,20]$ ). Dendritic cells isolated from the lamina propria (LP) of the gut wall express very few Tolllike receptors, or are unresponsive to their ligands $[21,22]$. After inflammatory stimuli or bacterial infection, LP dendritic cells release the cytokine interleukin10 (IL-10), but fail to induce the Th1 type of effector $\mathrm{T}$ cells [20-25]; also, a population of LP dendritic cells can drive the differentiation of Th17 $\mathrm{T}$ cells [26] and support IgA production [22]. This subpopulation expresses CD70 and several receptors for ATP, which is involved in conferring the ability of DCs to promote Th17 differentiation [27]. Interestingly, ATP is released by commensal bacteria, indicated by the fact that gut cavities of germ-free mice are devoid of ATP and consequently Th17 cells are reduced in numbers in the lamina propria. Along similar lines, cytophaga-flavobacter-bacteroidetes (CFB) have been shown to favour the development of Th17 cells [28], while a major member of the Firmicutes family, Faecalibacterium prausnitzii, offers its host protection against Crohn's disease, as it has been shown that a reduction in the number of this bacteria is associated with a higher risk of postoperative recurrence of ileal disease [29].

It would be interesting to understand the capacity of F. prausnitzii to produce ATP. A subtype of CD103positive mesenteric lymph node (MLN) or LP dendritic cells is involved in T-cell-mediated regulation of experimental colitis [30], the differentiation of CD $25^{+}$Foxp $3^{+}$ $\mathrm{T}$ regulatory cells $\left(\mathrm{T}_{\mathrm{reg}}\right)[31,32]$, and in imparting guthoming properties to $\mathrm{T}$ cells in both mice [33] and humans [34]. Interestingly, $\mathrm{CD}_{103^{+}}$and $\mathrm{CD} 103^{-}$intestinal dendritic cells seem to colonize different areas of the intestinal mucosa - the LP of the villi and the solitary intestinal lymphoid tissues, respectively [34]. Peyer's patch DCs release IL-6 [35] and retinoic acid and drive the development of gut-homing IgA-secreting B cells [36] and $\mathrm{T}$ cells [37-39]. Together, these findings suggest that gut dendritic cells are more prone to drive noninflammatory or tolerogenic responses. These could be the 'default' responses in the gut, aimed at sparing the induction of immune responses to commensal bacteria. 
These specialized functions of intestinal dendritic cells are in part imprinted by the local microenvironment. In particular, epithelial-cell-derived factors are important in the differentiation of non-inflammatory dendritic cells [40]. Intestinal epithelial cells release the cytokine thymic stromal lymphopoietin (TSLP), which inhibits IL-12 production by dendritic cells in response to bacteria and polarizes the T-cell response towards Th2 cells [27]. Similarly, impairment of NF- $\kappa B$ signaling in intestinal epithelial cells in mice by deletion of the protein kinase IKK $\beta$ results in decreased expression of TSLP and the upregulation of dendritic cell-derived subunit p40 of IL-12 [41]. This is associated with an inability to drive Th2 cells and to control whipworm (Trichuris) infection [41]. TSLP is also involved in driving the production of tolerogenic dendritic cells in humans (I.D. Iliev and M.R., unpublished work), while TSLPconditioned dendritic cells drive the production of $\mathrm{T}_{\text {reg }}$ in the mouse [42]. Intestinal epithelial cells can also release transforming growth factor- $\beta$ (TGF $\beta$ ) and retinoic acid, which are responsible for promoting the development of $\mathrm{CD}_{103^{+}}$tolerogenic dendritic cells from $\mathrm{CD} 103^{-}$cells (I.D. Iliev and M.R., unpublished work). In addition, TSLP favors the release of the cytokines BAFF and APRIL by epithelial cell-conditioned dendritic cells and supports IgA class switching directly in the lamina propria $[43,44]$ in humans. Notably, incubation of bacteria with epithelial cells in vitro results in differing levels of TSLP and TGF $\beta 1$ upregulation, depending on the nature of the bacteria, with Gram-negative species being the most effective [45]. This suggests that bacteria can indirectly control dendritic cell activation via their interaction with epithelial cells through the release of 'educating' factors.

Hence, the interaction between commensals and epithelial cells has two important consequences. First, it inhibits the generation of inflammatory responses that would normally occur when 'virgin' epithelial cells meet bacteria. Second, it induces the release of educating factors that drive the differentiation of tolerogenic dendritic cells whose function is to promote the differentiation of $\mathrm{T}$ regulatory cells and IgA-producing B cells (Figure 1).

\section{Future directions}

It is becoming clear that the interaction of commensals with epithelial cells and dendritic cells is fundamental to keep peace at mucosal surfaces. However, this symbiosis has risks as well as benefits. Indeed, the homeostatic balance is based on very fragile interactions. Sudden variations in the microbiota or in the immune response could lead to the development of a colitogenic flora. This has recently been demonstrated in mice lacking the gene
Figure I. Commensals participate in intestinal homeostasis.

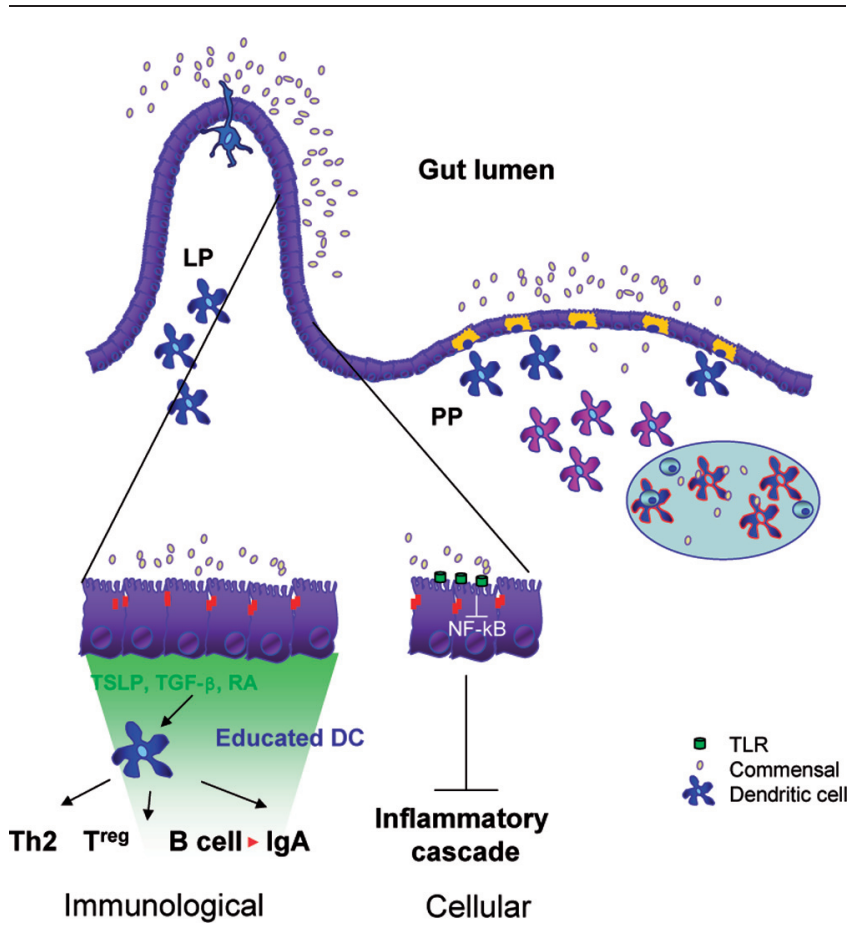

On the left-hand side of the figure, the interaction of commensals with intestinal epithelial cells results in inhibition of NF- $\triangle \mathrm{B}$ activation and blockade of the inflammatory cascade (cellular events) and the release of 'educating' factors (TGF- $\beta$ and TSLP, immunological events). Binding of commensals or their components to Toll-like receptors (TLRs) on the apical faces of epithelial cells can result in inhibition of NF- $\triangle B$ activation by blocking $\mathbb{Q} B$ degradation or favoring the egress of RelA from the nucleus. TSLP, TGF $\beta$ and retinoic acid (RA) released by activated epithelial cells educate non-inflammatory and tolerogenic resident dendritic cells (dark blue cells), which can extend their processes into the intestinal lumen. These cells enable sampling of non-harmful commensal bacteria and presentation of their antigens and may be involved in tolerance induction under homeostatic conditions. The educated dendritic cells are shown driving the development of Th2 or $\mathrm{T}_{\text {reg }}$ cells (pale blue cells) in intestinal lymphoid tissues such as mesenteric lymph nodes (not shown) and Peyer's patches (right hand side). They also drive B-cell class switch recombination to $\lg A$ both in the lamina propria and in Peyer's Patches. Immunity to pathogenic bacteria is initiated by non-educated dendritic cells (purple cells). LP, lamina propria; PP, Peyer's patch.

for the transcription factor T-bet $\left(T-b e t^{-1}\right)$ [46], in which the inability to control production of the inflammatory cytokine tumor necrosis factor (TNF) results in infectious colitis. It is still not clear how bacteria interact with epithelial cells - whether they are able to hydrolyze mucus and reach the apical surface - or whether bacterial products are sufficient to induce tolerance. Furthermore, commensals are also likely to be coated with secretory immunoglobulins and might interact with epithelial cells only via IgA receptors whose nature is still unknown. 
Thus we are still far from having dissected out the mechanisms responsible for the fine balance between inflammation and tolerance. In vivo studies dissecting out the role of mucins, antimicrobial peptides and cell-cell interactions are required for a better understanding of bacteria-host interactions.

\section{Competing interests}

The author declares that she has no competing interests.

\section{Abbreviations}

IgA, immunoglobulin A; PRR, pattern recognition receptor; TLR, Toll-like receptor; ROS, reactive oxygen species; dendritic cells; LP, lamina propria; MLN, mesenteric lymph node; TSLP, thymic stromal lymphopoietin.

\section{Acknowledgments}

MR is supported by European Commission grants METAhit, ERC and IBDase, by the Crohn's and Colitis Foundation of America (CCFA), by the Associazione Italiana per la Ricerca sul Cancro (AIRC) and by the Italian Ministry of Health.

\section{References}

I. Turnbaugh PJ, Ley RE, Hamady M, Fraser-Liggett CM, Knight R, Gordon Jl: The human microbiome project. Nature 2007, 449:804- 10.

2. Umesaki $\mathrm{Y}$, Setoyama $\mathrm{H}$ : Structure of the intestinal flora responsible for development of the gut immune system in a rodent model. Microbes Infect 2000, 2:1343-51.

3. Macpherson AJ, Gatto D, Sainsbury E, Harriman GR, Hengartner H, Zinkernagel RM: A primitive $T$ cell-independent mechanism of intestinal mucosal IgA responses to commensal bacteria. Science 2000, 288:2222-6.

4. Rescigno M, Urbano M, Valzasina B, Francolini M, Rotta G, Bonasio R, Granucci F, Kraehenbuhl JP, Ricciardi-Castagnoli P: Dendritic cells express tight junction proteins and penetrate gut epithelial monolayers to sample bacteria. Nat Immunol 200I, 2:36I-7.

FI000 Factor 6.0 Must Read

Evaluated by Virginia Miller 17 Oct 2001

5. Lee J, Mo JH, Katakura K, Alkalay I, Rucker AN, Liu YT, Lee HK, Shen C, Cojocaru G, Shenouda S, Kagnoff M, Eckmann L, Ben-Neriah Y, Raz E: Maintenance of colonic homeostasis by distinctive apical TLR9 signalling in intestinal epithelial cells. Nat Cell Biol 2006, 8:1327-36

FI000 Factor 6.0 Must Read

Evaluated by Charles Bevins 27 Feb 2007

6. Lee J, Gonzales-Navajas JM, Raz E: The "polarizing-tolerizing" mechanism of intestinal epithelium: its relevance to colonic homeostasis. Semin Immunopathol 2008, 30:3-9.

7. Rakoff-Nahoum S, Paglino J, Eslami-Varzaneh F, Edberg S, Medzhitov R: Recognition of commensal microflora by toll-like receptors is required for intestinal homeostasis. Cell 2004, I I 8:229-4I.

FI000 Factor 9.3 Exceptional

Evaluated by Ralph Isberg 4 Aug 2004, David Relman 13 Aug 2004, Eric Denkers 18 Aug 2004, Steve Ward 31 Aug 2004, Emmanuelle Caron 7 Sep 2004, Christopher Karp 12 Oct 2004, Richard Grencis 17 Nov 2004, Lieping Chen 18 Jan 2005, Eric Stabb 19 Jan 2005
8. Fukata M, Michelsen KS, Eri R, Thomas LS, Hu B, Lukasek K, Nast CC, Lechago J, Xu R, Naiki Y, Soliman A, Arditi M, Abreu MT: Toll-like receptor- 4 is required for intestinal response to epithelial injury and limiting bacterial translocation in a murine model of acute colitis. Am J Physiol Gastrointest Liver Physiol 2005, 288: GI055-65.

9. Cario E, Gerken G, Podolsky DK: Toll-like receptor 2 controls mucosal inflammation by regulating epithelial barrier function. Gastroenterology 2007, 132:1359-74.

FI000 Factor 6.4 Must Read

Evaluated by Jerrold Turner 7 Jun 2007, Hannah Carey 18 Sep 2007

10. Vijay-Kumar M, Sanders CJ, Taylor RT, Kumar A, Aitken JD, Sitaraman SV, Neish AS, Uematsu S, Akira S, Williams IR, Gewirtz AT: Deletion of TLR5 results in spontaneous colitis in mice. J Clin Invest 2007, I 1 7:3909-2I.

FI000 Factor 6.6 Must Read

Evaluated by Charles Bevins 21 Nov 2007, David Underhill 29 Nov 2007, Jeffrey Weiser 4 Jan 2008

II. Lotz M, Gütle D, Walther S, Ménard S, Bogdan C, Hornef MW: Postnatal acquisition of endotoxin tolerance in intestinal epithelial cells. J Exp Med 2006, 203:973-84.

FI000 Factor 3.0 Recommended

Evaluated by Caetano Reis e Sousa 28 Apr 2006

12. Foster SL, Hargreaves DC, Medzhitov R: Gene-specific control of inflammation by TLR-induced chromatin modifications. Nature 2007, 447:972-8.

FI000 Factor 8.I Exceptional

Evaluated by Caetano Reis e Sousa 13 Jun 2007, Michael McChesney 22 Jun 2007, Patrick Matthais I4 Aug 2007

13. Neish AS, Gewirtz AT, Zeng H, Young AN, Hobert ME, Karmali V, Rao AS, Madara JL: Prokaryotic regulation of epithelial responses by inhibition of IkappaB-alpha ubiquitination. Science 2000, 289:1560-3.

14. Tien MT, Girardin SE, Regnault B, Le Bourhis L, Dillies MA, Coppée JY, Bourdet-Sicard R, Sansonetti PJ, Pédron T: Anti-inflammatory effect of Lactobacillus casei on Shigella-infected human intestinal epithelial cells. J Immunol 2006, 176:1228-37.

15. Kelly D, Campbell JI, King TP, Grant G, Jansson EA, Coutts AG, Pettersson S, Conway S: Commensal anaerobic gut bacteria attenuate inflammation by regulating nuclear-cytoplasmic shuttling of PPAR-gamma and RelA. Nat Immunol 2004, 5: I04- 12.

FI000 Factor 6.7 Must Read

Evaluated by Michael Gold 2 Jan 2004, Eric Denkers 8 Jan 2004, Kaja Murali-Krishna 6 Feb 2004, Casey Weaver II Mar 2004

16. Kumar A, Wu H, Collier-Hyams LS, Hansen JM, Li T, Yamoah K, Pan ZQ, Jones DP, Neish AS: Commensal bacteria modulate cullindependent signaling via generation of reactive oxygen species. EMBO J 2007, 26:4457-66.

FI000 Factor 6.0 Must Read

Evaluated by Wilhelm Boland 6 Nov 2007

17. Munford RS, Varley AW: Shield as signal: lipopolysaccharides and the evolution of immunity to gram-negative bacteria. PLoS Pathog 2006, 2:e67.

18. Macpherson AJ, Uhr T: Induction of protective IgA by intestinal dendritic cells carrying commensal bacteria. Science 2004, 303:1662-5.

FI000 Factor 4.8 Must Read

Evaluated by Maria Rescigno 15 Apr 2004, Klaus Ley 5 May 2004

19. Coombes JL, Powrie F: Dendritic cells in intestinal immune regulation. Nat Rev Immunol 2008, 8:435-46.

20. Iwasaki A: Mucosal dendritic cells. Annu Rev Immunol 2007, 25:38|-4I8. 
21. Monteleone I, Platt AM, Jaensson E, Agace WW, Mowat AM: IL-I0dependent partial refractoriness to Toll-like receptor stimulation modulates gut mucosal dendritic cell function. Eur J Immunol 2008, 38:1533-47.

22. Uematsu S, Fujimoto K, Jang MH, Yang BG, Jung YJ, Nishiyama M, Sato S, Tsujimura T, Yamamoto M, Yokota Y, Kiyono H, Miyasaka M, Ishii KJ, Akira S: Regulation of humoral and cellular gut immunity by lamina propria dendritic cells expressing Toll-like receptor 5 . Nat Immunol 2008, 9:769-76.

FI000 Factor 3.4 Recommended

Evaluated by Maria Rescigno I 3 Jun 2008, Anthony DeFranco I 9 Jun 2008, Mohamed Sayegh 19 Jun 2008, Rachel Caspi 15 Aug 2008

23. Iwasaki A, Kelsall BL: Freshly isolated Peyer's patch, but not spleen, dendritic cells produce interleukin 10 and induce the differentiation of $\mathbf{T}$ helper type 2 cells. J Exp Med 1999, 190: 229-39.

24. Rimoldi M, Chieppa M, Salucci V, Avogadri F, Sonzogni A, Sampietro GM, Nespoli A, Viale G, Allavena P, Rescigno M: Intestinal immune homeostasis is regulated by the crosstalk between epithelia cells and dendritic cells. Nat Immunol 2005, 6:507-14.

FI000 Factor 6.4 Must Read

Evaluated by Jürgen Heesemann I Aug 2005, Ulrich von Andrian I5 Aug 2005

25. Chirdo FG, Millington OR, Beacock-Sharp H, Mowat AM: Immunomodulatory dendritic cells in intestinal lamina propria. Eur J Immunol 2005, 35: I83I-40.

26. Denning TL, Wang YC, Patel SR, Williams IR, Pulendran B: Lamina propria macrophages and dendritic cells differentially induce regulatory and interleukin $\mathbf{1 7}$-producing $\mathbf{T}$ cell responses. Nat Immunol 2007, 8: 1086-94.

FI000 Factor 6.7 Must Read

Evaluated by Eric Denkers 3 Oct 2007, Maria Rescigno 3 Oct 2007, Luciano Adorini 19 Nov 2007, Reina Mebius 17 Jan 2008

27. Atarashi K, Nishimura J, Shima T, Umesaki Y, Yamamoto M, Onoue M, Yagita $H$, Ishii N, Evans R, Honda K, Takeda K: ATP drives lamina propria $\mathbf{T}(\mathrm{H})$ I7 cell differentiation. Nature 2008, 455:808-I2.

FI000 Factor 8.3 Exceptional

Evaluated by Torben Lund 17 Oct 2008, Klaus Ley 24 Oct 2008, Steve Ward 28 Oct 2008, Ivana Novak 29 Oct 2008

28. Ivanov II, Frutos RL, Manel N, Yoshinaga K, Rifkin DB, Sartor RB, Finlay BB, Littman DR: Specific microbiota direct the differentiation of IL-17-producing T-helper cells in the mucosa of the small intestine. Cell Host Microbe 2008, 4:337-49.

FI000 Factor 8.0 Exceptional

Evaluated by Klaus Ley 24 Oct 2008, David Underhill 30 Oct 2008

29. Sokol H, Pigneur B, Watterlot L, Lakhdari O, Bermudez-Humaran LG Gratadoux IJ, Blugeon S, Bridonneau C, Furet JP, Corthier G, Grangette C, Vasquez N, Pochart P, Trugnan G, Thomas G, Blottiere HM, Dore J, Marteau P, Seksik P, Langella P: Faecalibacterium prausnitzii is an anti-inflammatory commensal bacterium identified by gut microbiota analysis of Crohn disease patients. Proc Natl Acad Sci U S A 2008, 105:1673I-6.

30. Annacker $\mathrm{O}$, Coombes JL, Malmstrom V, Uhlig HH, Bourne T, Johansson-Lindbom B, Agace WW, Parker CM, Powrie F: Essentia role for $\mathrm{CDIO3}$ in the $\mathrm{T}$ cell-mediated regulation of experimental colitis. J Exp Med 2005, 202:105I-6I.

FI000 Factor 3.0 Recommended

Evaluated by Richard Grencis 4 Nov 2005

31. Sun CM, Hall JA, Blank RB, Bouladoux N, Oukka M, Mora JR, Belkaid $Y$ : Small intestine lamina propria dendritic cells promote de novo generation of Foxp3 $\mathrm{T}$ reg cells via retinoic acid. J Exp Med 2007, 204:1775-85.

FI000 Factor 6.0 Must Read

Evaluated by Arthur Hurwitz 2 Jan 2008
32. Coombes JL, Siddiqui KR, Arancibia-Cárcamo CV, Hall J, Sun CM, Belkaid Y, Powrie F: A functionally specialized population of mucosal CDI03+ DCs induces Foxp3+ regulatory T cells via a TGF-beta and retinoic acid dependent mechanism. I Exp Med 2007, 204: 1757-64

33. Johansson-Lindbom B, Svensson M, Pabst O, Palmqvist C, Marquez G Förster R, Agace WW: Functional specialization of gut CDI03+ dendritic cells in the regulation of tissue-selective $\mathbf{T}$ cell homing. J Exp Med 2005, 202:1063-73.

FI000 Factor 3.0 Recommended

Evaluated by Richard Grencis 9 Nov 2005

34. Jaensson E, Uronen-Hansson H, Pabst O, Eksteen B, Tian J, Coombes L, Berg PL, Davidsson T, Powrie F, Johansson-Lindbom B, Agace WW: Small intestinal CDI03+ dendritic cells display unique functional properties that are conserved between mice and humans. J Exp Med 2008, 205:2139-49.

35. Sato A, Hashiguchi M, Toda E, Iwasaki A, Hachimura S, Kaminogawa S CDIIb+ Peyer's patch dendritic cells secrete IL-6 and induce IgA secretion from naive B cells. J Immunol 2003, I 7I:3684-90.

36. Mora JR, Iwata M, Eksteen B, Song SY, Junt T, Senman B, Otipoby KL, Yokota A, Takeuchi H, Ricciardi-Castagnoli P, Rajewsky K, Adams DH, von Andrian UH: Generation of gut-homing IgAsecreting B cells by intestinal dendritic cells. Science 2006, 3| $4: 1157-60$

FI000 Factor 6.6 Must Read

Evaluated by Torben Lund I Dec 2006, Leo Lefrancois I Dec 2006, Maria Rescigno 4 Dec 2006

37. Mora JR, Bono MR, Manjunath N, Weninger W, Cavanagh LL, Rosemblatt M, Von Andrian UH: Selective imprinting of guthoming T cells by Peyer's patch dendritic cells. Nature 2003, 424:88-93.

FI000 Factor 6.9 Must Read

Evaluated by Stella C. Knight I 4 Jul 2003, Hans Acha-Orbea 2 I Jul 2003, James Campbell 4 Aug 2003, Reina Mebius 8 Aug 2003, Klaus Ley I Sep 2003

38. Johansson-Lindbom B, Svensson M, Wurbel MA, Malissen B, Marquez G, Agace W: Selective generation of gut tropic $T$ cells in gutassociated lymphoid tissue (GALT): requirement for GALT dendritic cells and adjuvant. J Exp Med 2003, 198:963-9.

39. Stagg AJ, Kamm MA, Knight SC: Intestinal dendritic cells increase T cell expression of alpha4beta7 integrin. Eur J Immunol 2002, 32:1445-54

40. Iliev ID, Matteoli G, Rescigno M: The yin and yang of intestinal epithelial cells in controlling dendritic cell function. J Exp Med 2007, 204:2253-7.

4I. Zaph C, Troy AE, Taylor BC, Berman-Booty LD, Guild KJ, Du Y, Yost EA, Gruber AD, May MJ, Greten FR, Eckmann L, Karin M, Artis D: Epithelial-cell-intrinsic IKK-beta expression regulates intestinal immune homeostasis. Nature 2007, 446:552-6.

FI000 Factor 8.2 Exceptiona

Evaluated by Maria Rescigno 22 Mar 2007, Thomas Wynn 20 Apr 2007, Richard Grencis 26 Jun 2007

42. Besin G, Gaudreau S, Menard M, Guindi C, Dupuis G, Amrani A: Thymic stromal lymphopoietin and thymic stromal lymphopoietin-conditioned dendritic cells induce regulatory $\mathrm{T}$-cell differentiation and protection of NOD mice against diabetes. Diabetes 2008, 57:2107-17.

43. Xu W, He B, Chiu A, Chadburn A, Shan M, Buldys M, Ding A Knowles DM, Santini PA, Cerutti A: Epithelial cells trigger frontline immunoglobulin class switching through a pathway regulated by the inhibitor SLPI. Nat Immunol 2007, 8:294-303.

FI000 Factor 6.4 Must Read

Evaluated by Maria Rescigno 22 Mar 2007, Dan Conrad 23 Mar 2007

44. He B, Xu W, Santini PA, Polydorides AD, Chiu A, Estrella J, Shan M, Chadburn A, Villanacci V, Plebani A, Knowles DM, Rescigno M, 
Cerutti A: Intestinal bacteria trigger $\mathbf{T}$ cell-independent immunoglobulin $\mathbf{A}(2)$ class switching by inducing epithelial-cell secretion of the cytokine APRIL. Immunity 2007, 26:812-26.

FI000 Factor 3.0 Recommended

Evaluated by Nadine Cerf-Bensussan 10 Aug 2007

45. Zeuthen LH, Fink LN, Frøkiaer $\mathrm{H}$ : Epithelial cells prime the immune response to an array of gut-derived commensals towards a tolerogenic phenotype through distinct actions of thymic stromal lymphopoietin and transforming growth factor-beta. Immunology 2008, I 23:197-208.

46. Garrett WS, Lord GM, Punit S, Lugo-Villarino G, Mazmanian SK, Ito S, Glickman JN, Glimcher LH: Communicable ulcerative colitis induced by T-bet deficiency in the innate immune system. Cell 2007, 13 I:33-45.

FI000 Factor 4.8 Must Read

Evaluated by Eric Denkers I5 Oct 2007, Scott Lesley I8 Oct 2007 